\title{
Revolusi Gaya Belajar untuk Fungsi Otak
}

\author{
M. Edy Waluyo \\ STAIN Syekh Abdurrahman Siddik Bangka Belitung \\ Email: m.edywaluyo@gmail.com
}

\begin{abstract}
This paper elaborate on an attempt to maximize the function of brain as a form of learning revolution. Learn properly is not an issue of whether or not a student pass the test. The meaning of learn is broader than a success of passing the exams. This is certainly related to the fun learning during the process of maximizing the ability to achieve success. Each student has a different learning styles depending on his/her character. There are four different models of learning that has been known today, ie sketch, sound, tactics, and movement. Students who have studied the model using the sketch tends to be easier to understand the information that they see. While those who have learned how to use the sound tends to be easier to capture verbal information from the teacher. Students who have a tendency to learn with tactics models require a touch of emotion. The kinesthetic learning models require movement in the learning process so that children learn more successfully.
\end{abstract}

Keyword: learning, model of learning, successful learning

\begin{abstract}
Abstrak
Tulisan ini menguraikan upaya memaksimalkan kerja sebagai bentuk revolusi belajar. Belajar dengan benar bukan permasalahan tentang lulus atau tidaknya seorang siswa dalam ujian. Makna belajar lebih luas daripada sekedar dapat lulus ujian. Hal ini tentu berhubungan dengan pembelajaran yang menyenangkan selama proses memaksimalkan kemampuan untuk meraih kesuksesan. Setiap siswa mempunyai cara belajar yang berbeda-beda tergantung karakter masingmasing siswa. Ada empat macam model belajar yang telah dikenal saat ini, yaitu gambar, suara, taktik, dan gerakan. Siswa yang mempunyai model belajar menggunakan gambar cenderung akan mudah memahami informasi yang telah dilihat. Sementara mereka yang mempunyai cara belajar menggunakan suara cenderung akan mudah menangkap informasi verbal dari guru. Siswa yang mempunyai kecenderungan belajar dengan model taktik memerlukan sentuhan emosi. Adapun model belajar kinestetik menuntut gerakan dalam proses pembelajaran sehingga belajar anak lebih berhasil.
\end{abstract}

Kata kunci: pembelajaran, pola pembelajaran, pembelajaran sukses 


\section{A. Pendahuluan}

Banyak pelajar maupun mahasiswa yang sering salah memahami makna belajar. Belajar diartikan sekedar membaca dan mengerjakan tugas-tugas dari guru atau dosen. Oleh karena itu, tidak sedikit yang mengalami kejenuhan dalam belajar. Bahkan, enggan untuk belajar atau malah takut belajar. Dalam pengertian berikut, belajar menjadi berat karena dianggap sebagai beban, bukan bagian dari proses memahami dan mencintai materi pelajaran.

Pada dasarnya, belajar bukan diartikan bagaimana seorang siswa dapat mengerjakan ujian, tetapi sejauh mana hati siswa terpaut pada pelajarannya. Dalam arti lain, mereka hanya belajar untuk menghadapi ujian atau menjadi pembelajaran sepanjang hidup. Belajar menurut Sumadi Suryabrata seperti mendapatkan perbendaharaan kata-kata baru, menghafal syair, menghafal nyanyian dan lain-lain. ${ }^{1}$

Betapa banyak anak yang ketika diperintah orang tuanya untuk belajar, kemudian sang anak masuk kamar, bahkan mengunci pintu kamarnya. Tetapi apa yang terjadi di dalam kamar? Anak sekedar membolak-balikkan lembar demi lembar buku pelajarannya, menatap sekilas pelajaran-pelajaran yang sudah dilalui hari ini. Episode berikutnya adalah membuat gambar-gambar abstrak yang tidak jelas temanya, tetapi sekaligus mengungkapkan kebosanan belajar yang luar biasa.

Apalagi sehari-hari di sekolah dengan sistem belajar yang terasa begitu kaku dan linier. Tugas guru mengajar, siswa belajar. Guru menerangkan, siswa mendengarkan. Guru memberikan soal, siswa mengerjakan. Belajar haruslah serius dan terkesan tegang, miskin senyuman. Jika ada siswa yang banyak bertanya, guru menganggapnya sebagai siswa bawel, cerewet dan banyak omong. Intinya, suasana belajar menjadi semakin membosankan. Siswa terpenjara oleh sistem pendidikan yang ada, tetapi mereka tidak dapat berbuat apa-apa.

Berdasarkan fenomena tersebut muncul teori-teori baru tentang pembelajaran, di antaranya ialah Quantum Learning yang digagas oleh Dr. Georgi Lozanov yang bergelut pada persoalan suggestology atau suggestopedia. Prinsip dari eksperimen yang

1 Sumadi Suryabrata, Psikologi Pendidikan, (Jakarta: Raja Grafindo Persada, 2014), hlm. 230. 
dilakukannya adalah sugesti dapat mempengaruhi hasil belajar. Dan, setiap detail apa pun dapat memberikan sugesti yang positif maupun negatif. ${ }^{2}$ Dalam inner mind pelajar adalah bagaimana kegiatan belajar itu mampu menyugesti dirinya bahwa belajar ini sangat mudah, menyenangkan dan bermanfaat dalam jangka dekat, menengah ataupun panjang. Salah satu usaha penting yang dapat dilakukan untuk membangkitkan semangat belajar adalah mendesain pembelajaran dalam suasana yang menyenangkan. ${ }^{3}$ Pembelajaran yang menyenangkan berusaha untuk membangun konsepsi baru yakni belajar bukanlah sebagaimana yang selama ini dibayangkan.

\section{B. Karakter Gaya Belajar}

Setiap siswa memiliki karakter gaya belajar yang berbeda dengan siswa yang lain. Ada empat gaya belajar yang dikenal, yaitu visual, auditori, taktil dan kinestetik. Siswa yang memiliki kecenderungan gaya belajar visual, akan mudah memahami informasi terhadap apa yang ia lihat, baik dalam bentuk buku maupun gambar. Sementara mereka yang memiliki kecenderungan gaya belajar auditori, cukup baik menangkap informasi verbal dari guru. Begitu pula, siswa yang memiliki kecenderungan gaya belajar taktil, akan belajar melalui sentuhan yang sertai dengan keterlibatan emosionalnya, dan siswa yang memiliki kecenderungan gaya belajar kinestetik akan lebih menonjol daya serapnya dengan motoriknya.

Otak Albert Einstain memiliki volume yang sama dengan ratarata orang dewasa, yaitu $1,4 \mathrm{~kg}$, secara fisik tidak ada bedanya, baik sisi warna maupun bentuk. Setelah diteliti, ternyata jumlah sel neuronnya juga sama, yaitu satu triliun sel neuron. Sel-sel neuron ini kemudian diteliti lebih lanjut dan barulah ditemukan perbedaannya. Sel neuron Albert lebih banyak yang sudah terkoneksi dengan sel neuron lainnya. Sedangkan otak orang ratarata, sel neuronnya belum banyak yang terkoneksi. Tetapi lebih mengejutkan sekaligus menggembirakan adalah setelah dihitung dan diperkirakan, ternyata sel neuron otak Albert yang sudah terkoneksi tidak lebih dari 3\% dari keseluruhan jumlah sel neuron.

2 Muhammad Noer, Hypno Teaching For Success Learning, (Yogyakarta: Bintang Pustaka Abadi, 2010), hlm. 6-7.

3 Ngainun Naim, Menjadi Guru Inspiratif, (Yogyakarta: Pustaka Pelajar, 2009), hlm. 175. 
Pertanyaannya, kalau si genius Albert saja baru 3\% potensi otaknya yang digunakan, lalu berapa persen potensi otak kita?

Sebagai gambaran perbandingan, kita bisa mengambil data pada tahun 1997, ketika dunia terjadi booming internet, dalam tiga hari mampu membangun koneksi 200 juta di antara pengguna komputer di dunia. Sementara itu, otak kita mampu membuat jaringan 15 kali lebih besar, yakni satu detik sama dengan jaringan internet tiga hari. Maka, sangatlah wajar jika Gordon Dryden menyatakan, "You're the owner of the world's most powerful computer" (Anda adalah pemilik komputer paling hebat di dunia). ${ }^{4}$

Maka dari itu, rasa takut untuk memulai belajar adalah hal pertama kali yang harus dibuang jauh-jauh oleh pelajar maupun mahasiswa, itulah yang membuat jaringan otak kita berada pada "status quo", status di mana otak mapan dalam ketidaktahuan. Semakin banyak belajar, membaca, berdiskusi, mengamati dan menganalisa sesuatu, maka semakin banyak pula koneksi-koneksi sel neuron di otak kita. Sehingga secara sadar atau tidak, sebenarnya kita sudah bertambah pintar dari sebelumnya.

Menurut perkiraan ada sekitar 12 miliar neuron dalam Sistem Saraf Pusat (SSP). Tiga perempat dari neuron tersebut terletak dalam korteks serebri, tempat informasi ditransmisikan melalui sistem saraf. Proses ini, mencakup tidak hanya penentuan tentang respons-respons yang sesuai dan efektif, tetapi juga penyimpanan memori dan perkembangan dari motorik asosiatif dan pola pikir. ${ }^{5}$

Untuk dapat belajar dengan maksimal, seorang guru dan pebelajar seharusnya memahami gaya belajar, yaitu: gaya belajar visual (visual learner), gaya belajar auditif (auditory learner) dan gaya belajar kinestetik (tactual learner).

1. Gaya Belajar Visual (Visual Learner)

Visual learner adalah gaya belajar di mana gagasan, konsep, data dan informasi lainnya dikemas dalam bentuk gambar dan teknik. Siswa yang memiliki tipe belajar visual memiliki interest yang tinggi ketika diperlihatkan gambar, grafik, grafis organisatoris. Seperti jaring, peta konsep dan ide peta, plot, dan ilustrasi visual lainnya. Beberapa teknik yang

${ }^{4}$ Farida Yunita Sari dan Mukhlis, Hypno Learning; 1 Menit Bikin Gila Belajar dan Siap Jadi Juara, (Jakarta: Visimedia, 2011), hlm. 16 - 17.

5 Tutu April Ariani, Sistem Neuro behaviour, (Jakarta: Salemba Medika, 2012), hlm. 9. 
digunakan dalam belajar visual untuk meningkatkan keterampilan berpikir dan belajar, lebih mengedepankan peran penting mata sebagai penglihatan (visual). Pada gaya belajar tersebut dibutuhkan banyak model dan metode pembelajaran yang digunakan dengan menitikberatkan pada peragaan.

Media pembelajarannya adalah objek-objek yang berkaitan dengan pelajaran tersebut, atau dengan cara menunjukkan alat peraganya langsung pada siswa atau menggambarkannya di white board atau papan tulis. Bahasa tubuh dan ekspresi muka gurunya juga sangat penting peranannya untuk menyampaikan materi pelajaran. Mereka cenderung untuk duduk di depan agar dapat melihat dengan jelas. Mereka berpikir menggunakan gambar-gambar di otak dan belajar lebih cepat dengan menggunakan tampilantampilan visual. Seperti halnya diagram, buku pelajaran bergambar, CD interaktif, digital content dan video (MTV). Di dalam kelas anak visual lebih suka mencatat sampai detaildetailnya untuk mendapatkan informasi.

2. Gaya Belajar Auditif (Auditory Learner)

Auditory learner adalah suatu gaya belajar pada siswa yang belajar melalui mendengarkan. Siswa yang memiliki gaya belajar auditori akan mengandalkan kesuksesan dalam belajarnya melalui telinga (alat pendengarannya). Oleh karena itu, guru sebaiknya memperhatikan para siswa hingga ke alat pendengarannya. Anak yang mempunyai gaya belajar auditori dapat belajar lebih cepat dengan menggunakan diskusi verbal dan mendengarkan penjelasan apa yang dikatakan guru. Anak dengan gaya belajar auditori dapat mencermati makna yang disampaikan oleh guru melalui verbal simbol atau suara, tinggi rendahnya, kecepatan berbicara dan hal-hal auditori lainnya. Anak-anak seperti ini dapat menghafal lebih cepat melalui membaca teks dengan keras atau mendengarkan media audio.

\section{Gaya Belajar Kinestetik (Tactual Learner)}

Tactual learner adalah gaya siswa belajar dengan cara melakukan, menyentuh, merasa, bergerak dan mengalami. Anak yang mempunyai gaya belajar kinestetik mengandalkan belajar melalui bergerak, menyentuh dan melakukan tindakan. Anak seperti ini sulit untuk duduk diam berjam-jam, karena keinginan mereka untuk beraktivitas dan eksplorasi sangatlah 
kuat. Siswa yang bergaya belajar seperti ini belajarnya melalui gerak dan sentuhan. ${ }^{6}$ Oleh karena itu, pembelajaran yang dibutuhkan adalah pembelajaran yang bersifat kontekstual dan praktik.

\section{Hasil Belajar}

Mengenai hasil belajar, UNESCO menuangkannya dalam empat pilar pembelajaran yang meliputi:

1. Belajar Mengetahui (Learning to Know)

Belajar mengetahui berkenaan dengan perolehan, penguasaan, dan pemanfaatan informasi. Dewasa ini, terdapat ledakan informasi dan pengetahuan. Hal itu bukan saja disebabkan oleh adanya perkembangan yang sangat cepat dalam bidang ilmu dan teknologi. Akan tetapi, karena perkembangan teknologi yang sangat cepat, terutama dalam bidang elektronika, memungkinkan sejumlah besar informasi dan pengetahuan tersimpan, bisa diperoleh dan disebarkan secara cepat dan hampir menjangkau seluruh planet bumi. Belajar mengetahui merupakan kegiatan untuk memperoleh, memperdalam, dan memanfaatkan pengetahuan.

Pengetahuan diperoleh dengan berbagai upaya perolehan pengetahuan, seperti membaca, mengakses internet, bertanya, dan mengikuti kuliah. Pengetahuan dikuasai melalui hafalan, tanya jawab, diskusi, latihan pemecahan masalah dan penerapan. Pengetahuan dimanfaatkan untuk mencapai berbagai tujuan, memperluas wawasan, meningkatkan kemampuan, memecahkan masalah dan belajar lebih lanjut.

Ada beberapa hal yang merupakan landasan filosofis dari kegiatan belajar, yaitu:

a. Bagaimana siswa pertama-tama dan terutama harus "belajar bagaimana belajar"dan belajar bagaimana berfikir.

b. Belajar harus menyenangkan di samping membangun percaya diri.

${ }^{6}$ Rusman (dkk), Pembelajaran Berbasis Teknologi Informasi dan Komunikasi; Mengembangkan Profesionalitas Guru, (Jakarta: Raja Grafindo Persada, 2011), hlm. 33-34. 
c. Pengetahuan harus disampaikan dengan pendekatan multisensori dan multimodel dengan menggunakan berbagai bentuk kecerdasan.

d. Orang tua khususnya dan masyarakat umumnya harus terlibat sepenuhnya dalam pendidikan anak-anak.

e. Sekolah harus menjadi persiapan sebenarnya bagi dunia yang sebenarnya.

f. Prinsip-prinsip Manajemen Kualitas Total (MKT) dalam bisnis harus mengilhami dunia persekolahan. ${ }^{7}$

2. Belajar Berbuat atau Berkarya (Learning to Do)

Agar seseorang mampu menyesuaikan diri dan beradaptasi dalam masyarakat yang berkembang sangat cepat, maka seseorang perlu belajar berkarya. Belajar berkarya berhubungan erat dengan belajar mengetahui, sebab pengetahuan mendasari perbuatan. Dalam konsep komisi UNESCO, belajar berkarya ini mempunyai makna khusus, yaitu dalam kaitan dengan vokasional. Belajar berkarya adalah belajar atau berlatih menguasai keterampilan dan kompetensi kerja.

Seiring dengan tuntutan perkembangan industri dan perusahaan, maka keterampilan dan kompetisi kerja ini, juga berkembang semakin tinggi, tidak hanya pada tingkat keterampilan, kompetensi teknis atau operasional, tetapi sampai dengan kompetensi profesional. Karena tuntutan pekerjaan pada dunia industri dan perusahaan terus meningkat, maka individu yang akan memasuki dan/atau telah masuk di dunia industri dan perusahaan perlu terus berkarya. Mereka harus mampu doing much (berusaha berkarya banyak).

3. Belajar Hidup Bersama (Learning to Live Together)

Dalam kehidupan global, kita tidak hanya berinteraksi dengan beraneka kelompok etnik, daerah, budaya, ras, agama, dan profesi saja, tetapi hidup bersama dan bekerja sama dengan aneka kelompok tersebut. Agar mampu berinteraksi, berkomunikasi, bekerja sama dan hidup bersama antar kelompok dengan baik, maka dituntut belajar hidup bersama. Tiap kelompok memiliki latar belakang pendidikan, kebudayaan, tradisi, dan tahap perkembangan yang berbeda,

${ }^{7}$ Suryabrata, Psikologi Pendidikan ..., hlm. 328. 
agar bisa bekerja sama dan hidup rukun, mereka harus banyak belajar hidup bersama, being sociable (berusaha membina kehidupan bersama).

4. Belajar Menjadi Diri Sendiri yang Utuh (Learning to Be)

Tantangan kehidupan yang berkembang cepat dan sangat kompleks, menuntut pengembangan manusia secara utuh. Manusia yang seluruh aspek kepribadiannya berkembang secara optimal dan seimbang, baik aspek intelektual, emosi, sosial, fisik maupun moral. Dengan demikian, maka manusia dituntut banyak belajar mengembangkan seluruh aspek kepribadiannya. Sebenarnya tuntutan perkembangan kehidupan global, bukan hanya menuntut manusia berkembang secara menyeluruh dan utuh, namun manusia utuh yang unggul. Maka dari itu, mereka harus berusaha agar dapat mencapai banyak keunggulan (being excellence). ${ }^{8}$ Keunggulan diperkuat dengan moral yang kuat. Individuindividu global harus berupaya bermoral kuat atau being morally.

\section{Memahami Kerja Otak}

Lebih dari tiga dekade penelitian tentang belahan otak, adalah mungkin untuk menyimpulkan penemuan-penemuan tersebut ke dalam empat perbedaan pokok.

1. Belahan otak sebelah kiri mengontrol bagian tubuh sebelah kanan; belahan otak sebelah kanan mengontrol bagian tubuh sebelah kiri. Otak-otak kita itu kontralateral, maksudnya adalah masing-masing belahan otak mengontrol belahan tubuh lainnya yang bersebelahan. Itulah mengapa stroke pada bagian kiri otak seorang akan membuat sulit orang itu untuk menggerakkan bagian kanan tubuhnya, begitu pula sebaliknya. Sekitar 90 persen penduduk menggunakan tangan kanan, itu berarti bahwa dalam sekitar 90 persen penduduk, belahan otak kiri mengontrol gerakan-gerakan penting seperti tulisan tangan, makan, dan menggerakkan mouse komputer.

2. Belahan otak sebelah kiri bersifat berurutan; belahan otak sebelah kanan bersifat simultan. Belahan kiri pada khususnya bagus dalam mengenali peristiwa-peristiwa serial yakni peristiwa-peristiwa yang terjadi secara berurutan dan

\footnotetext{
${ }^{8}$ Rusman, Pembelajaran Berbasis Teknologi Informasi ..., hlm. 13-15.
} 
mengontrol urutan-urutan perilaku. Belahan kiri juga dilibatkan dalam mengontrol perilaku-perilaku serial. Fungsifungsi serial yang dilakukan oleh belahan kiri mencakup aktivitas-aktivitas verbal, seperti berbicara, memahami perkataan orang lain, membaca dan menulis. Dapat disimpulkan bahwa belahan otak kanan adalah gambar, sedangkan belahan kiri adalah ribuan kata-kata.

3. Belahan otak sebelah kiri mengkhususkan pada teks; belahan otak kanan pada konteks. Pada kebanyakan orang, bahasa bermula dalam belahan otak kiri. (Ini bisa berlaku bagi 95 persen pengguna tangan kanan dan 70 persen pengguna tangan kiri. Sisanya, sekitar 8 persen dari penduduk, dalam pembagian kerja bahasa lebih rumit). Akan tetapi, belahan otak kanan tidak menyerahkan tanggung jawab yang penuh kepada belahan otak kiri. Seharusnya dua sisi tersebut melakukan fungsi-fungsi yang saling melengkapi.

4. Hemat kata, belahan otak kiri memperhatikan apa yang dikatakan; belahan sebelah kanan memfokuskan pada bagaimana ia dikatakan - isyarat-isyarat nonverbal yang sering emosional yang disampaikan melalui pandangan, ekspresi wajah dan intonasi.

5. Belahan otak sebelah kiri menganalisa rincian-rincian; belahan otak sebelah kanan menyintesiskan keseluruhan perspektif tentang sesuatu. Secara umum, belahan sebelah kiri ikut serta dalam analisa informasi, sebaliknya belahan sebelah kanan dikhususkan pada perpaduan; ia pada khususnya bagus dalam mengumpulkan unsur-unsur yang terpisah untuk memahami sesuatu secara utuh. Analisa dan perpaduan mungkin dua cara menafsirkan informasi yang paling fundamental. ${ }^{9}$ yaitu:

Ada tiga tahap yang berlangsung dalam memori manusia,

1. Encoding merupakan proses pengodean terhadap apa yang dipersepsi dengan cara mengubahnya menjadi simbol-simbol atau gelombang-gelombang listrik tertentu, sesuai peringkat yang ada pada organisasi atau merupakan suatu proses

${ }^{9}$ Daniel H. Pink, Otak Kanan Manusia, (Yogyakarta: Think, 2010), hlm. 32-39. 
mengubah informasi ke dalam bentuk yang sesuai dengan sifat-sifat memori manusia.

2. Storage merupakan proses penyimpanan terhadap apa yang telah diproses dalam encoding. Storage bisa disebut retensi, yaitu proses pengendapan informasi yang diterima ke dalam suatu tempat tertentu.

3. Retrieval merupakan proses pemulihan kembali atau mengingat kembali apa yang telah disimpan sebelumnya. Proses mengingat kembali pada suatu proses mencari dan menemukan informasi yang disimpan dalam memori untuk digunakan kembali bila dibutuhkan. ${ }^{10}$

Sementara itu, berdasarkan lamanya kemampuan otak untuk menyimpan informasi, ada tiga jenis memori, yaitu memori sensoris, memori jangka pendek, dan memori jangka panjang.

1. Memori Sensoris. Memori sensoris mencatat apa yang kita lihat, dengar, raba, rasa dan bau. Dengan kata lain, memori sensoris mencatat hal-hal yang ada di dalam indra kita. Memori sensoris bersifat sangat singkat. Meskipun kita mentransfernya ke memori jangka pendek, data itu akan menghilang segera setelah apa yang kita rasakan berakhir. Sebagai contoh, ketika kita berjalan selama beberapa menit, kita melihat ratusan hal. Meskipun saat berjalan itu perhatian kita tertuju pada suatu hal yang kita lihat, maka akan segera terlupakan oleh sesuatu yang lain yang lebih menarik perhatian kita.

2. Memori Jangka Pendek. Memori jangka pendek berlangsung sedikit lebih lama. Selama kita menaruh perhatian pada sesuatu, kita dapat mengingatnya dalam memori jangka pendek. Misalnya, ketika kita terus-menerus mengulang sebuah nomor telepon sampai kita bisa menuliskannya, maka nomor tersebut akan tersimpan dalam memori kita selama kita aktif memikirkannya. Namun, jika kita berhenti memberi perhatian pada nomor itu, maka memori kita terhadap nomor itu akan terhapus dalam waktu $10-20$ detik. Dalam mengingat sesuatu berikutnya, otak akan mentransfernya ke memori jangka panjang. Dengan demikian, proses mengingat

10 Walgito dalam Agus Warseno dan Ratih Komorojati, Super Learning: Praktik Belajar-Mengajar yang Serba Efektif dan Mencerdaskan, (Yogyakarta: Diva Press, 2011), hlm. 22. 
nomor telepon ini pada dasarnya adalah suatu cara untuk memindahkan nomor dari memori jangka pendek ke memori jangka panjang.

3. Memori Jangka Panjang. Memori jangka panjang dapat menyimpan sejumlah informasi yang hampir tak terbatas. Memori jangka panjang berisi persepsi dan ide-ide yang berkisar dari beberapa menit hingga awal kehidupan masa lalu kita. Memori jangka panjang seperti hard disk besar dari sebuah komputer raksasa, di mana informasi tidak terbatas dapat disimpan seumur hidup. Dalam memori tersebut, kita mampu membangun ide-ide dan pengalaman, serta menunjukkan kembali informasi ketika kita membutuhkannya. ${ }^{11}$

Mencermati mekanisme kerja otak di atas, upaya-upaya berikut ini dapat diharapkan lebih meningkatkan kemampuan otak untuk merekam informasi, dalam hal ini berkaitan dengan bagaimana belajar dapat berjalan secara maksimal:

1. Buat sesuatu yang ingin dipelajari menjadi sesuatu yang menarik, atau paling tidak dicari sisi-sisi yang menarik. Sehingga kemampuan otak untuk mengingat lebih besar. Caranya dengan menggunakan indera untuk melihat lebih dalam dan intens, jika mungkin gunakan alat peraga untuk memicu sel-sel otak membuat koneksi yang lebih banyak. Jika tidak, imajinasikan obyek yang pada awalnya abstrak, dijadikan seolah-olah konkret, setelah itu berselancarlah dalam dunia ide untuk menemukan gelombang-gelombang ilmu pengetahuan.

2. Prinsip pengulangan. Sesuatu yang senantiasa diulang-ulang akan menjadi kebiasaan, dari kebiasaan itulah memori yang sudah terekam di otak sewaktu-waktu dapat dipanggil kembali. Pengulangan itu bukan hanya sekedar penyebutannya, tetapi dapat berupa peta konsep suatu mata pelajaran/mata kuliah yang ditempelkan di dinding kamar. Ketika intensitas mata membaca dan mencermati gambar dilakukan. Walaupun hanya sekilas, otak akan merespons dengan halus sehingga bangunan pengetahuan dapat terbangun kokoh.

11 Walgito dalam Warseno dan Komorojati, Super Learning ..., hlm. 24-27. 
3. Orang yang terbiasa menggunakan pikirannya untuk membangun suatu ide, atau berupaya untuk memecahkan masalah dengan mempertimbangkan sebab akibat atau berpandangan futuristik, biasanya memiliki keterampilan untuk berpikir secara sistematis. Dengan kemampuan berpikir seperti itu, bangunan ilmu pengetahuan yang telah tersusun bukan saja tertata rapi dalam folder pengetahuan dalam otaknya, tetapi sewaktu-waktu dibutuhkan dapat dipanggil dengan mudah. Ingat bahwa kemampuan memori jangka panjang seperti hard disk dengan kapasitas yang hampir tanpa batas.

Ada beberapa hal yang merupakan landasan filosofis dari kegiatan belajar, yaitu:

1. Bagaimana siswa pertama-tama dan terutama harus "belajar bagaimana belajar"dan belajar bagaimana berpikir.

2. Belajar harus menyenangkan di samping membangun percaya diri.

3. Pengetahuan harus disampaikan dengan pendekatan multisensori dan multimodel dengan menggunakan berbagai bentuk kecerdasan.

4. Orang tua khususnya dan masyarakat umumnya harus terlibat sepenuhnya dalam pendidikan anak-anak.

5. Sekolah harus menjadi persiapan sebenarnya bagi dunia yang sebenarnya.

6. Prinsip-prinsip Manajemen Kualitas Total (MKT) dalam bisnis harus mengilhami dunia persekolahan. ${ }^{12}$

Dalam hal ini ada empat konsep dasar yang ditawarkan oleh Colin Rose dan Malcom J. Nichols berkaitan dengan belajar, yaitu:

1. Belajar bagaimana belajar. Sistem pendidikan yang didasarkan pada prinsip-prinsip psikologis yang telah usang, tidak benar, dan terlalu menyederhanakan, juga sering berbenturan keras dengan keterampilan belajar alamiah yang dimiliki anak-anak, akan mengajarkan kepada mereka untuk tidak percaya dan menekan keterampilan mereka dalam belajar. Selain itu, akan menggerakkan anak-anak secara sistematis belajar untuk tidak belajar;

${ }^{12}$ Suryabrata, Psikologi Pendidikan ..., hlm. 328. 
2. Belajar bisa menyenangkan. Semakin menggembirakan dalam belajar, semakin banyak yang akan dapat diserap. Jika siswa dibawa oleh pendidikan institusional ke dalam suasana belajar yang tidak menyenangkan, maka betapa keras guru harus bekerja untuk meyakinkan para siswa bahwa belajar merupakan kegiatan yang menarik, bahkan menyenangkan.

3. Belajar dengan semua kecerdasan. Sebagian siswa membutuhkan penggambaran visual dan fisik dari konsepkonsep yang diajarkan. Sebagian yang lainnya lebih suka kerja otak yang abstrak. Sebagian lainnya lagi perlu gagasangagasan yang diungkapkan secara verbal dengan cara-cara yang berbeda. Sebagian lagi memetik keuntungan dari penjelasan bahan-bahan belajar oleh teman-temannya. Sebagian pelajar yang lainnya belajarnya lebih baik jika diberi kesempatan bermain sejenak dengan bahan-bahan yang akan dipelajarinya, seperti yang dilakukan di lab sains sebelum mereka menemukan informasi kuncinya. Dan siswa yang lain lebih suka jika diberikan jawaban secara langsung.

4. Belajar dengan kekuatan orang tua. Raymond J. Wlodkowski dan Judith H. Jaynes menyatakan, "Orang tua agaknya merupakan faktor yang paling berpengaruh atas motivasi anak dalam belajar. Pengaruh formatif mereka atas motivasi belajar anak-anaknya mempunyai pengaruh pada setiap tahap perkembangan yang berlangsung sepanjang periode masa sekolah lanjutan atas dan di luar itu." 13

Lebih lanjut keterkaitan antara lingkungan dan seluruh elemen gaya belajar teknologis dapat dilihat pada skema berikut:

${ }^{13}$ Collin Rose dan Malcolm J, Nichols, Accelerated Learning for The 21th Century; Cara Belajar Cepat Abad XXI. (Jakarta: Nuansa, 2003), hlm. 328-321. 


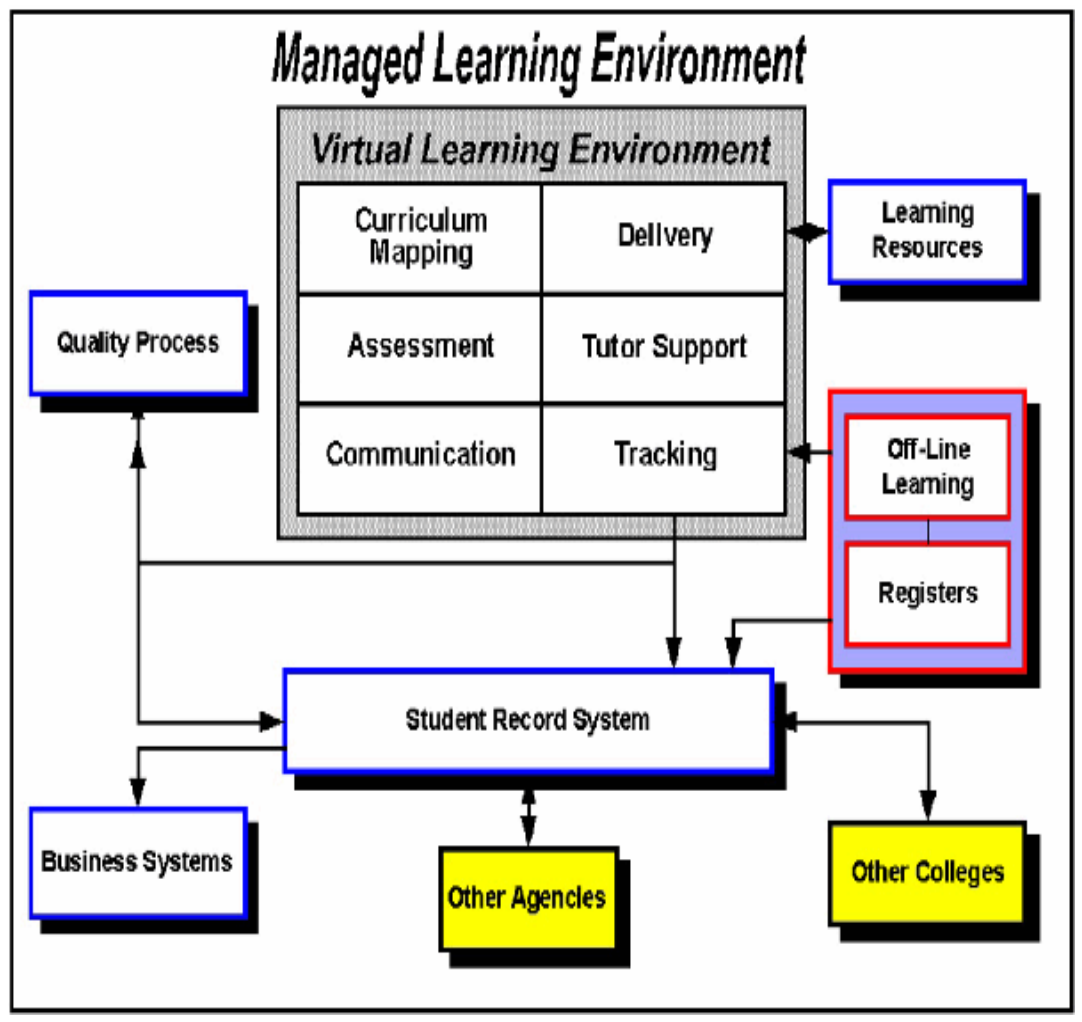

Sumber: http: \\www.finntrack.com 2010

Teknik belajar mnemonik (mnemonic technique) adalah sebuah teknik yang dapat membantu pelajar mengelola memori jangka panjangnya dengan baik, biasanya dilakukan dengan menggunakan singkatan atau kalimat yang mudah diingat. Contoh penggunaan teknik belajar mnemonik adalah sebagai berikut:

1. Untuk mengingat warna pelangi dalam bahasa Inggris, kalimat "Richard of York Gave Battle in Vain", setiap inisial yang disebutkan merujuk pada warna-warna pelangi (Red, Orange, Yellow, Green, Blue, Indigo, Violet).

2. Untuk mengingat danau besar di Amerika menggunakan akronim Homes, sesuai dengan huruf awal lima danau tersebut: Huron, Ontario, Michigan, Erie dan Superior. ${ }^{14}$

${ }^{14}$ Wikipedia The Free Encylopedia, Mnemonic, en.wikipedia.org/wiki/ Mnemonic, diakses tanggal 08 Januari 2015. 
Teknik belajar yang diperkenalkan oleh Tony Buzan pada tahun 1974, seorang ahli pengembangan potensi manusia dari Inggris mengungkapkan metode untuk memaksimalkan potensi pikiran manusia dengan menggunakan otak kanan dan kirinya secara simultan. Beberapa kata kunci yang menjadi fondasi dasar mind mapping adalah sebagai berikut:

1. Mulai dari tengah dengan gambar tema, gunakan minimal 3 warna.

2. Gunakan gambar, simbol, kode dan dimensi di seluruh peta pikiran yang dibuat.

3. Pilih kata kunci dan tulis dengan huruf besar atau kecil.

4. Tiap kata/gambar harus sendiri dan mempunyai garis sendiri.

5. Garis-garis itu saling dikaitkan, mulai dari tengah yaitu gambar Tema Utama. Garis bagian tengah tebal, organis, dan mengalir dari pusat keluar, menjulur seperti akar, atau pancaran cahaya.

6. Buat garis sama panjangnya dengan gambar/kata.

7. Gunakan warna dan kode rahasia sendiri di peta pikiran yang dibuat.

8. Kembangkan gaya penuturan, penekanan tertentu, dan penampilan khas di peta pikiran yang dibuat. Peta pikiran setiap orang tidak harus sama meskipun tema yang dibahas sama.

9. Gunakan kaidah asosiasi di peta pikiran yang dibuat.

10. Biarkan peta pikiran itu jelas, menggunakan hierarki yang runtut, urutan yang jelas dengan jangkauan sampai ke cabangcabang paling ujung. ${ }^{15}$

15 Wikipedia Ensiklopedia Bebas, Pemetaan Pikiran; id.wikipedia/ wiki/Pemetaan_pikiran, diakses 19 Juli 2012. 


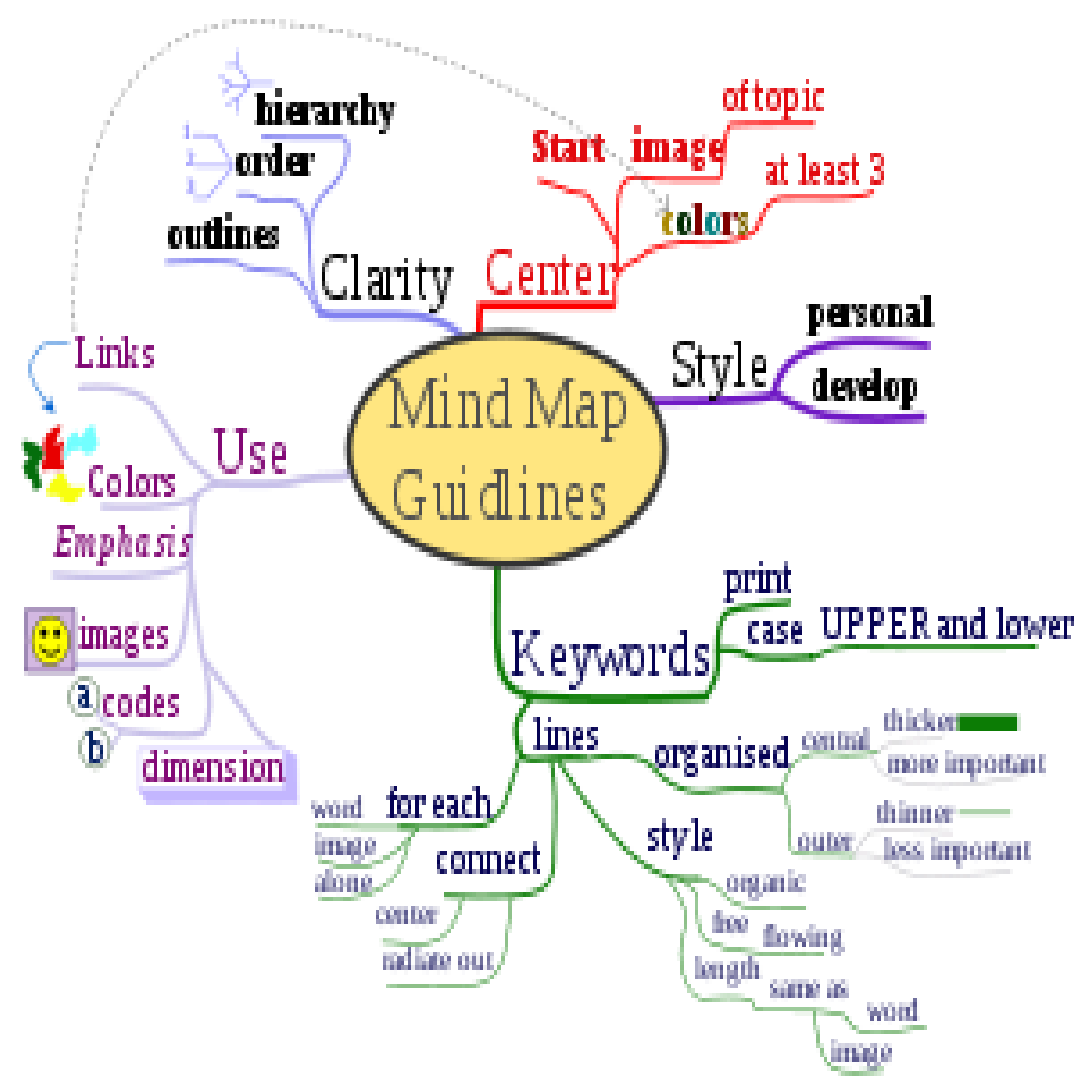

Untuk menjadi pembelajar yang unggul, kiranya perlu memperhatikan lima pilar, yaitu: rasa ingin tahu, optimisme, keikhlasan, konsistensi, dan pandangan visioner. ${ }^{16}$ Tidak dapat dipungkiri, Lingkungan belajar merupakan salah satu faktor yang memberikan kontribusi positif terhadap keberhasilan belajar. Masyarakat yang terkondisikan dengan jam wajib belajar, bukan saja menimbulkan suasana belajar yang kondusif, akan tetapi memberikan kesan tersendiri bagi siswa yang berada dalam lingkungan tersebut. Lingkungan belajar dapat berupa lingkungan virtual, di mana masing-masing memfasilitasi tercapainya suasana belajar yang kondusif.

16 James Petras dalam Musthofa Rembangy, Pendidikan Transformatif; Pergulatan Kritis Merumuskan Pendidikan di Tengah Pusaran Arus Globalisasi,(Yogyakarta: Teras, 2010), hlm. 138-139. 


\section{E. Penutup}

Pemahaman terhadap konsep belajar memang sangat beragam. Bahkan sebagian para siswa memaknai belajar merupakan sesuatu yang sukar, kaku dan monoton (linier). Hal ini disebabkan karena pemahaman mereka terhadap konsep belajar, hanya sebatas fenomena saja. Artinya, belajar divisualisasikan seperti guru mengajar, siswa mengajar atau soal-soal dan buku-buku. Sehingga muncul stigma bahwa belajar membosankan.

Padahal perlu diketahui, otak manusia pada dasarnya memiliki cakupan memori yang luas. Albert Einstein misalnya, ternyata sel saraf pada otaknya yang digunakan hanyalah $3 \%$ dari potensi otaknya. Itu saja, ia dikenal sebagai 'orang genius'. Maka dari itu, otak kita sangat luar biasa dan kita perlu bangkit terhadap keterpurukan tersebut, yang menimbulkan ketidaktahuan.

Oleh sebab itu, dalam tulisan ini dipaparkan berbagai hal terkait fungsi otak yang tidak dimanfaatkan secara optimal. Sehingga perlu adanya revolusi gaya belajar seseorang, karena fungsi otak yang sangat luar biasa mau dioptimalkan secara maksimal.

Dari tulisan di atas, untuk melakukan sebuah revolusi gaya belajar dapatlah disarikan beberapa hal:

1. Mencari sisi-sisi menarik dari sebuah proses belajar, sehingga menemukan sugesti positif sehingga belajar menjadi sebuah kegiatan yang menyenangkan.

2. Menemukan gaya belajar kita dan memaksimalkannya sesuai dengan karakteristik masing-masing gaya belajar, atau belajar dengan semua potensi kecerdasan yang dimiliki.

3. Mencari tahu bagaimana kita dapat belajar dengan baik.

4. Belajar mengingat dengan teknik mnemonik.

5. Untuk memahami unit-unit pelajaran dapat dirangkum dengan teknik mind map.

\section{Kepustakaan}

Ariani,Tutu April, Sistem Neuro Behaviour, (Jakarta: Salemba Medika, 2012).

Naim, Ngainun, Menjadi Guru Inspiratif, (Yogyakarta: Pustaka Pelajar, 2009). 
Noer, Muhammad, Hypno Teaching for Success Learning, (Yogyakarta: Bintang Pustaka Abadi, 2010).

Pink, Daniel H., Otak Kanan Manusia, (Yogyakarta: Think, 2010).

Rembangy, Musthofa, Pendidikan Transformatif: Pergulatan Kritis Merumuskan Pendidikan di Tengah Pusaran Arus Globalisasi, (Yogyakarta: Teras, 2010).

Rose, Colin dan Malcolm J. Nicholl, Cara Belajar Cepat Abad XXI, (Jakarta: Nuansa, 2003).

Rusman (dkk), Pembelajaran Berbasis Teknologi Informasi dan Komunikasi: Mengembangkan Profesionalitas Guru, (Jakarta: Raja Grafindo Persada, 2011).

Sari, Farida Yunita dan Mukhlis, Hypno Learning: 1 Menit Bikin Gila Belajar dan Siap Jadi Juara, (Jakarta: Visimedia, 2011).

Suryabrata, Sumadi, Psikologi Pendidikan, (Jakarta: Raja Grafindo Persada, 2014).

Agus Warseno dan Ratih Komorojati, Super Learning: Praktik Belajar-Mengajar yang Serba Efektif dan Mencerdaskan, (Yogyakarta: Diva Press, 2011).

Wikipedia The Free Encylopedia. Mnemonic. en.wikipedia.org/wiki/Mnemonic. diakses tanggal 08 Januari 2015. 
